\title{
Оксана КВАСНИЦя
}

\section{ФІНАНСОВЕ ЗАБЕЗПЕЧЕННЯ ПРОДОВОАЬЧОї БЕЗПЕКИ ДОМОГОСПОДАРСТВ}

Розглянуто стан продовольчої безпеки домогосподарств. Зазначено, що продовольча безпека на рівні крайни не завжди гарантує продовольчу безпеку домогосподарства й окремих осіб. Проаналізовано динаміку витрат домогосподарств на харчові продукти, визначено структуру харчування домогосподарств. Запропоновано напрями удосконалення фінансового забезпечення сільськогосподарських виробників та підвищення купівельної спроможності населення. Обгрунтовано висновок, що створення ефективної системи фінансового забезпечення продовольчої безпеки країни неможливе без консолідації фінансових ресурсів держави, агробізнесу й іниих підприємницьких структур та домогосподарств зокрема.

Ключові слова: продовольча безпека, сукупні витрати домогосподарств, споживчі сукупні витрати населення, фінансове забезпечення продовольчої безпеки.

\section{Оксана КВАСНИЦА}

Финансовое обеспечение продовольственной безопасности домохозяйсть

Рассмотрено состояние продовольственной безопасности домохозяйств. Отмечено, что продовольстеенная безопасность на уровне страны не всегда гарантирует продовольственную безопасность домохозяйства и отдельных лиц. Проанализирована динамика расходов домохозяйств на продукты питания, определена структура питания домохозяйств. Предложены направления совершенствования финансового обеспечения сельскохозяйственных производителей и повышения покупательной способности населения. Обоснован вывод, что создание эфффективной системы финансового обеспечения продовольственной безопасности страны невозможно без консолидации финансовых ресурсов государства, агробизнеса и других предпринимательских структур и домохозяйсте в частности.

Ключевые слова: продовольственная безопасность, совокупные расходы домохозяйств, потребительские совокупные расходы населения, финансовое обеспечение продовольственной безопасности.

\section{Oksana KVASNYTSIA}

\section{Financial provision of household food security}

Introduction. The issue of providing humanity with food rightly holds one of the leading places in the hierarchy of global problems. Food safety of a country is an indispensable condition and guarantees its sovereignty and independence, ensuring its sustainable social and economic development, population's high level and quality of life and reproduction of human capital.

(C) Оксана Квасниця, 2017 
The purpose of the article is to assess the state of food security of Ukraine, the definition of the role of households in ensuring food security and the justification of directions for improving financial leverage in the context of the implementation of Ukraine's agricultural and food potential.

Main results of the study. For Ukraine, the problem of ensuring food security is of particular importance, which is conditioned by the current state of development of the domestic agricultural and industrial complex, the increase of production in which is carried out mainly by an extensive way.

The most important conditions for achieving food security are: the potential physical availability of food for every person; economic opportunity of purchasing food by all social groups of the population, including disadvantaged ones, which is achieved by raising the standard of living or implementing the necessary measures of social security; consumption of high quality products in quantities sufficient for rational nutrition.

In order to increase the food security financial support, it is necessary to improve the financial component of the comprehensive food security mechanism, which aims at ensuring the application of economic instruments and creating conditions for attracting monetary resources for the functioning of the food security system through the creation of a multi-channel financing system.

Conclusions. Therefore, the main directions of improving the financial system for the purpose of ensuring food security of the country are: availability of financial and credit support to agricultural producers; introduction of innovations in agricultural production; regulation of conditions for foreign and domestic food trade through a system of tariff and non-tariff instruments; systemic measures to strengthen and extend the life expectancy of the population, wages and salary increase.

Keywords: investment activity of insurance company, investment strategy, assets of insurance company, insurance reserves, investment risk of insurance company, methods of neutralization investment risks.

JEL Classification: Q180.

Постановка проблеми. Проблема забезпечення людства продовольством правомірно посідає вагоме місце в ієрархії глобальних проблем. Продовольча безпека країн $є$ важливою умовою і гарантією збереження їх суверенітету й незалежності, забезпечення сталого соціально-економічного розвитку, формування високого рівня та якості життя населення, відтворення людського капіталу.

Аналіз останніх досліджень і публікацій. Питанням продовольчої безпеки велику увагу приділяли зарубіжні й вітчизняні вчені. Зокрема: О. Гойчук, М. Бабич, В. Бойко, П. Борщевський, Л. Дейнеко, М. Корецький, П. Лайко, Р. Мудрак, В. Настич, П. Саблук, Т. Савченко, В. Шамрай та ін. Проте дослідження проблем забезпечення продовольчої безпеки домогосподарств, зокрема в сучасних економічних умовах, не можна вважати вичерпаними.

Метою статті $€$ оцінка стану продовольчої безпеки України, визначення ролі домогосподарств у забезпеченні продовольчої безпеки та обґрунтування напрямків удосконалення фрінансових важелів у контексті реалізації агропродовольчого потенціалу України.

Виклад основного матеріалу дослідження. Національна безпека будь-якої держави будується на економічній безпеці, однією з важливих складових якої є продовольча компетентність, завдяки якій досягається сталий соціально-економічний розвиток сус- 
пільства та його демографічне відновлення. Продовольча безпека займає центральне місце у системі економічної безпеки держави і є важливою складовою їі суверенітету. Відповідно, початковий етап ії формування вимагає створення системи моніторингу, яка дає змогу визначити фактичний їі стан, розрахувати прогноз внутрішніх та зовнішніх загроз продовольчої безпеки. На цій основі розробляють заходи щодо локалізації та нейтралізації негативних фракторів, які впливають або можуть у майбутньому вплинути на зниження рівня безпеки. Система моніторингу продовольчої безпеки зосереджується на таких напрямках: агропродовольче виробництво, продовольчий ринок, споживання продовольства, харчування населення, якість та безпека продовольства.

Для України проблема забезпечення продовольчої безпеки має особливо важливе значення, що обумовлено сучасним станом розвитку вітчизняного агропромислового комплексу, нарощування виробництва у якому відбувається переважно екстенсивним шляхом.

Забезпечення продовольчої безпеки $є$ одним із основних напрямів державної політики з питань національної безпеки України [1]. Продовольча безпека держави захищеність життєвих інтересів людини, яка виражається у гарантуванні державою безперешкодного економічного доступу людини до продуктів харчування 3 метою підтримання ії життєдіяльності [2].

Продовольчу безпеку слід розглядати через призму кількох складових. По-перше, забезпечення продовольчої безпеки тієї чи іншої країни, а також її регіонів пов'язано з гарантованим стійким і достатнім рівнем виробництва продовольства, що у повному обсязі забезпечує запити її населення. По-друге, продовольча безпека може бути досягнута тільки тоді, коли гарантовані фрізичні й економічні умови населення у до- ступі до продовольства. По-третє, з метою досягнення продовольчої безпеки продукцію сільськогосподарського виробництва необхідно стабільно й у достатній кількості поставляти як на регіональні, так і світові ринки. І останнім елементом продовольчої безпеки є забезпечення населення доброякісним продовольством, що не завдає шкоди здоров'ю [3, с. 44].

У цьому контексті зазначимо, що потрібно забезпечити не тільки виробництво достатньої кількості високоякісного продовольства, а й підтримувати безперервні поставки сільськогосподарської продукції як на вітчизняні, так і світові ринки.

Відтак, продовольча безпека досягається за наявності відповідних систем та механізмів, що гарантують достатній обсяг виробництва і поставок продовольства й адекватно реагують на ризики, що можуть спричинити перебої в цій сфері. При цьому зауважимо, що для вирішення питань продовольчої безпеки необхідна тісна взаємодія всіх регіонів.

Завдяки дослідженням багатьох вітчизняних і зарубіжних вчених та міжнародних організацій поширюється розуміння того, що забезпечення продовольчої безпеки $є$ однією з найважливіших проблем для кожної країни і світу в цілому.

Підтримуючи думку науковців, можна констатувати, що продовольча проблема $\epsilon$ наслідком не лише глобалізації. Вона, ймовірно, є наслідком політики розвинених країн світу щодо гальмування економічного розвитку бідних країн і постійного захисту своїх інтересів, що суперечать інтересам країн із низьким рівнем розвитку та людства в цілому $[4$, с. 67].

Найважливішими умовами досягнення продовольчої безпеки є: потенційна фізична доступність харчових продуктів для кожної людини; економічна можливість придбання продовольства всіма соціальними групами 
населення, у тому числі й соціально незахищеними, що досягається шляхом підвищення життєвого рівня або реалізації необхідних заходів соціального захисту; споживання продуктів високої якості в кількості, достатній для раціонального харчування.

Більшість науковців, розглядаючи проблеми продовольчої безпеки, схиляються до думки, що основним критерієм при розгляді продовольчої безпеки має бути здатність держави гарантовано задовольняти потреби в продуктах харчування населення країни як за звичайних, так і надзвичайних умов, при цьому ії забезпечення має спиратися на нормальний фізіологічний та інтелектуальний рівні життєдіяльності населення. Вітчизняні науковці звернулися до розгляду і вирішення проблем продовольчої безпеки наприкінці 90-х років минулого століття, що було обумовлено результатами тодішньої жорсткої економічної кризи, яка спричинила обвальне падіння сільськогосподарського виробництва [5, с. 34].

Успішність забезпечення продовольчої безпеки ускладнюється деградацією соціальної ссрери, стан розвитку якої визначає рівень добробуту населення.

Розглянемо структуру сукупних витрат українських домогосподарств у 2006-2016 рр. Серед усіх сукупних витрат домогосподарств найбільшу питому вагу (більше ніж 90\%) становлять споживчі витрати. Найбільш вагомою статтею сукупних витрат домогосподарств залишаються витрати на харчування (включаючи харчування поза домом). Згідно зі статистичними даними, у 2016 р., порівняно з 2015 р., частка споживчих сукупних витрат у структурі сукупних витрат зросла на 1,01\%. 3 огляду на це, відбулося зниження частки неспоживчих сукупних витрат.

Аналіз структури сукупних витрат домогосподарств у період 2006-2016 рр. дає змогу в цілому виявити зростання частки витрат на продукти харчування, зниження частки витрат на непродовольчі товари і неспоживчих витрат (табл. 1), що в цілому $€$ негативною тенденцією.

Згідно зі статистичними даними, наведеними у табл. 1, у структурі сукупних витрат домогосподарств протягом 10 років найбільшу питому вагу займають витрати на продукти харчування та безалкогольні напої (близько 50\%). Наприклад, у 2016 р. частка цих витрат зменшилась на $5 \%$, і вони становили 49,8\% від споживчих сукупних витрат, що свідчить про низький рівень доходів населення та неможливість повноцінного продовольчого забезпечення, насамперед, фрізіологічних потреб індивіда, що і підштовхнуло населення до економії на інших видах витрат.

Структура сукупних витрат українських домогосподарств (\%) [6, с. 394; 7, с. 94]

\begin{tabular}{||c||c||c||c||c|c||c||c||c||c||c||c||}
\hline \multicolumn{1}{|c||}{$\begin{array}{c}\text { Витрати } \\
\text { домогосподарств }\end{array}$} & $\mathbf{2 0 0 6}$ & $\mathbf{2 0 0 7}$ & $\mathbf{2 0 0 8}$ & $\mathbf{2 0 0 9}$ & $\mathbf{2 0 1 0}$ & $\mathbf{2 0 1 1}$ & $\mathbf{2 0 1 2}$ & $\mathbf{2 0 1 3}$ & $\mathbf{2 0 1 4}$ & $\mathbf{2 0 1 5}$ & $\mathbf{2 0 1 6}$ \\
\hline $\begin{array}{l}\text { Споживчі сукупні витрати, } \\
\text { В тому числі: }\end{array}$ & 90,5 & 90,0 & 86,2 & 87,8 & 90,0 & 90,2 & 90,9 & 89,3 & 90,4 & 91,9 & 93,2 \\
\hline $\begin{array}{l}\text { продукти харчування } \\
\text { та безалкогольні напої }\end{array}$ & 53,2 & 51,4 & 48,9 & 50,0 & 51,6 & 56,5 & 55,5 & 50,4 & 51,5 & 54,8 & 49,8 \\
\hline $\begin{array}{l}\text { непродовольчі товари } \\
\text { та послуги }\end{array}$ & 39,1 & 38,6 & 37,3 & 37,8 & 38,4 & 33,7 & 35,4 & 38,9 & 38,9 & 37,1 & 40,5 \\
\hline \hline Неспоживчі сукупні витрати & 9,5 & 10,0 & 13,8 & 12,2 & 10,0 & 9,8 & 9,1 & 10,7 & 9,6 & 8,2 & 6,8 \\
\hline \hline
\end{tabular}




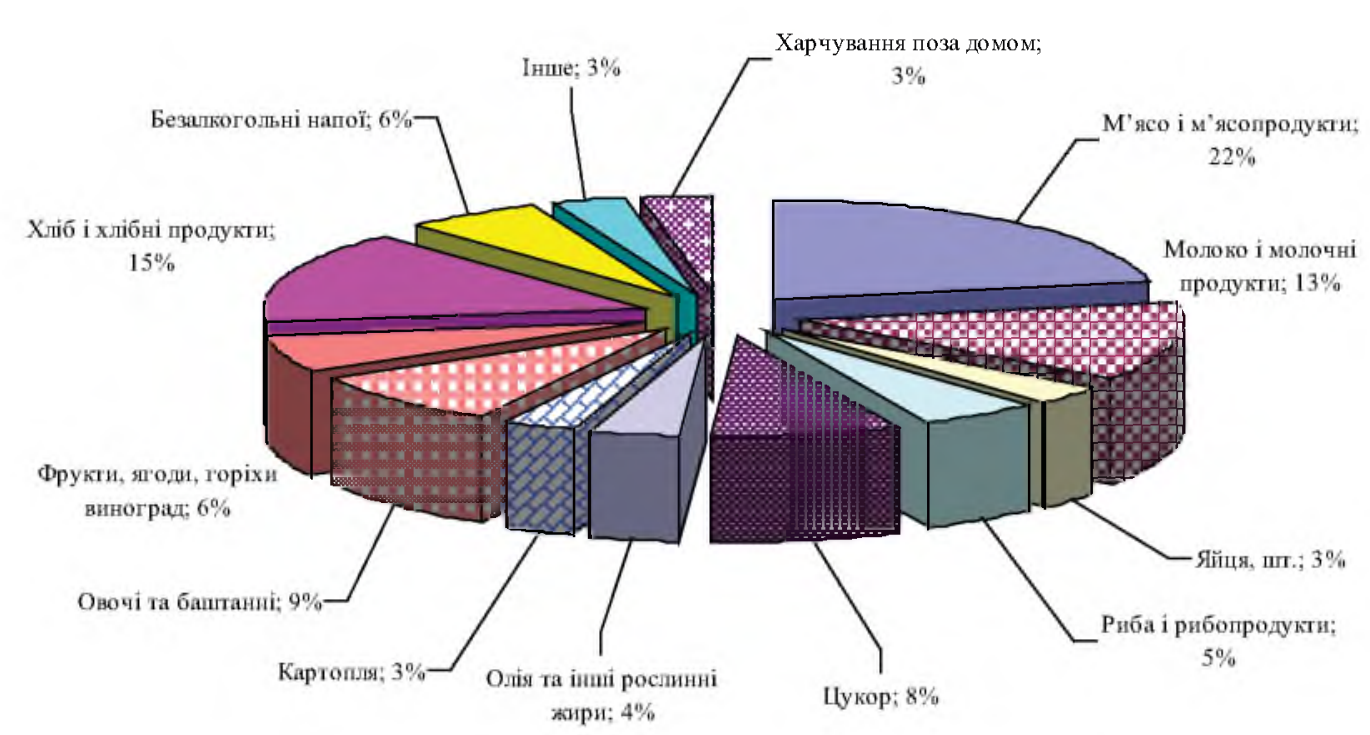

Рис. 1. Структура споживчих витрат на харчування у розрізі основних груп продовольства у 2016р., \%*

־ Побудовано на основі [8].

Оскільки левову частку у структурі споживчих сукупних витрат домогосподарств займають витрати на харчування, здійснимо їх структурний аналіз (рис. 1).

Що стосується структури споживчих витрат на продукти харчування, то, порівняно з 2015 р., значних змін не спостерігалося. Із рис. 1 видно, що найбільше домогосподарства здійснюють витрати на купівлю: м'яса і м'ясопродуктів-22\% (657 грн. надомогосподарство на місяць), хліба і хлібопродуктів 15\% (439 грн.), молока і молочних продуктів - 13\% (386 гривень).

Розглянемо відповідність споживання продуктів харчування раціональними нормам споживання та обсягу споживання продуктів харчування за споживчим кошиком (табл. 2).

Результати порівняння показників раціонального споживання продуктів харчування та фрактичного споживання у 2016 р. показали, що фрактичне споживання продуктів харчування майже за всіма групами продуктів, окрім картоплі, овочів та баштанних, хліба і хлібних продуктів, не досягає норм споживання, рекомендованих МОЗ на рівні від 0,08\% (яйця) до 44,8\% (фрукти, ягоди). Щодо результатів порівняння показників споживання продуктів за споживчим кошиком та фактичного споживання бачимо протилежну ситуацію: за такими групами продуктів, як молоко і молочні продукти, яйця, олія та інші рослинні жири, картопля, овочі та баштанні фактичне споживання перевищує кількісні показники обсягів споживання за споживчим кошиком, але при цьому залишаються групи продуктів, що не досягають норм споживання навіть за споживчим кошиком (цукор, риба і рибопродукти, фрукти, хліб та хлібні продукти). Такі зміни у споживанні можуть свідчити про недоступність або недостатню доступність продуктів харчування для більшості населення України. Для підтвердження цієї думки розглянемо індекс цін на продукти харчування (табл. 3).

Найбільше зростання цін відбулося у 2015 р., за окремими видами продуктів становило від 22,8 до $72,8 \%$, зниження ціни 
Таблиця 2

Норми і рівень споживання продуктів харчування населенням України, кг на рік [7, с. 9; 9]

\begin{tabular}{|c|c|c|c|c|c|c|c|c|}
\hline $\begin{array}{l}\text { № } \\
\Pi / \Pi\end{array}$ & Продукти & $\begin{array}{c}\text { Мінімаль- } \\
\text { ні норми } \\
\text { спожи- } \\
\text { вання }\end{array}$ & $\begin{array}{c}\text { Раціональ- } \\
\text { на норма } \\
\text { споживан- } \\
\text { ня** }^{*}\end{array}$ & $\begin{array}{c}\text { Cпо- } \\
\text { жив- } \\
\text { чий } \\
\text { кошик }\end{array}$ & $\begin{array}{l}\text { Фактич- } \\
\text { не спо- } \\
\text { живання } \\
\text { у } 2015 \text { р. }\end{array}$ & $\begin{array}{c}\text { Фактичне } \\
\text { спожи- } \\
\text { вання у } \\
2016 \text { р. }\end{array}$ & $\begin{array}{l}2016 \text { р.,\% до раці- } \\
\text { ональної норми } \\
\text { (індикатор достат- } \\
\text { ності споживання) }\end{array}$ & $\begin{array}{l}2016 \text { р., } \\
\% \text { до спо- } \\
\text { живчого } \\
\text { кошику }\end{array}$ \\
\hline 1. & М'ясо і м'ясопродукти & 52 & 83 & 53,0 & 50,9 & 51,4 & 0,62 & 0,97 \\
\hline 2. & $\begin{array}{l}\text { Молоко і молочні } \\
\text { продукти }\end{array}$ & 341 & 380 & 148,5 & 209,9 & 209,5 & 0,55 & 1,41 \\
\hline 3. & Яйця, шт & 231 & 290 & 220 & 280 & 267 & 0,92 & 1,21 \\
\hline 4. & Риба і рибопродукти & 12 & 20 & 13,0 & 8,6 & 9,6 & 0,48 & 0,74 \\
\hline 5. & Цукор & 32 & 38 & 37,0 & 35,7 & 33,3 & 0,88 & 0,9 \\
\hline 6. & $\begin{array}{l}\text { Олія та інші рослинні } \\
\text { жири }\end{array}$ & 8 & 13 & 7,1 & 12,3 & 11,7 & 0,9 & 1,65 \\
\hline 7. & Картопля & 96 & 124 & 95,0 & 137,5 & 139,8 & 1,13 & 1,47 \\
\hline 8. & Овочі та баштанні & 105 & 161 & 110 & 160,8 & 163,7 & 1,02 & 1,49 \\
\hline 9. & $\begin{array}{l}\text { Фрукти, ягоди, горіхи } \\
\text { виноград }\end{array}$ & 68 & 90 & 64 & 50,9 & 49,7 & 0,55 & 0,78 \\
\hline 10. & Хліб і хлібні продукти & 94 & 101 & 123,4 & 103,2 & 101,0 & 1,00 & 0,82 \\
\hline
\end{tabular}

* Затверджені Постановою Кабінету Міністрів України від 14.04.2000 р. № 656.

** За термінологією МОЗ України "Орієнтовний набір основних продовольчої сировини і харчових продуктів для забезпечення у середньому на душу населення на 2005-2015 роки”.

Таблиця 3

Динаміка індексу цін на основні продукти харчування (\%) [10, с. 37-38]

\begin{tabular}{|c|c|c|c|c|c|}
\hline \multirow{2}{*}{$\begin{array}{l}\text { № } \\
\text { ח/п }\end{array}$} & \multirow{2}{*}{ Продукти } & \multicolumn{4}{|c|}{ Індекс цін на основні продукти харчування } \\
\hline & & 2013p. & 2014p. & 2015p. & $2016 \mathrm{p}$. \\
\hline 1. & Продукти харчування та безалкогольні напої & 97,8 & 112,2 & 145,9 & 109,0 \\
\hline 1.1. & Продукти харчування & 97,6 & 112,2 & 144,4 & 108,5 \\
\hline 1.2 & Хліб в хлібопродукти & 101,1 & 113,4 & 160,6 & 111,1 \\
\hline 1.3. & Макаронні вироби & 101,9 & 110,6 & 154,1 & 107,2 \\
\hline 1.4 & М'ясо та м'ясопродукти & 98,1 & 110,9 & 131,3 & 107,3 \\
\hline 1.5. & Риба та продукти з риби & 96,1 & 117,1 & 160,2 & 105,1 \\
\hline 1.6 & Молоко, сир та яйця & 99,9 & 110,9 & 128,5 & 114,1 \\
\hline 1.7 & Олія та жири & 99,6 & 106,5 & 145,5 & 113,4 \\
\hline 1.8 & Фрукти & 88,0 & 124,8 & 172,4 & 98,2 \\
\hline 1.9 & Овочі & 88,3 & 104,1 & 130,8 & 93,6 \\
\hline 1.10. & Цукор & 92,3 & 146,3 & 136,0 & 117,8 \\
\hline 1.11 & Безалкогольні напої & 102,2 & 112,9 & 166,1 & 111,9 \\
\hline 2. & Алкогольні напої, тютюнові вироби & 108,4 & 116,7 & 133,2 & 112,6 \\
\hline
\end{tabular}


відбулося лише на один вид продукції - цукор $(10,3 \%)$. Середнє зростання цін на продукти харчування та безалкогольні напої $130,1 \%$. Таким чином, внаслідок зростання виробництва харчових продуктів у 2015 р. на 29,2\% відбулося лише зростання цін на продукцію, а збільшення питомої ваги у загальному обсязі реалізованої промислової продукції відбулося за рахунок зменшення виробництва частки інших видів продуктів промисловості.

Виявлені тенденції змін у структурі споживання продуктів харчування збігаються із динамікою індексу цін на ці продукти.

У 2016 р. спостерігалося рівномірне зменшення індексу цін майже на всі продукти в межах від 20\% до 30\%, Швидке сповільнення інфляції в 2016 р. відбулося, насамперед, завдяки послабленню інфляційного тиску, зумовленого макроекономічними фракторами, про що свідчить стрімке уповільнення базової інфрляції, на яку значний вплив мали сприятливі зміни щодо пропозиції сирих продуктів харчування.

у 2016 р. суттєво сповільнилося зростання цін на продукти харчування з високим ступенем обробки - до 5,7\% p/p (3 42,3\% p/p у 2015 р.), що пов'язано із вторинними ефректами від зниження інфолції сирих продуктів харчування. Водночас дезінфлляційний тренд дещо пригальмувався наприкінці 2016 р. як через подорожчання окремих видів сировини (молоко), так і через помірне погіршення інфляційних очікувань на тлі посилення девальваційного тиску та рішення уряду різко підвищити із січня 2017 р. мінімальну заробітну плату. Зростання цін на сирі продовольчі товари сповільнилося до $1,2 \%$ p/p за 2016 р. (із $40,7 \%$ p/p у 2015 р.). Стрімке зниження інфрляції сирих продуктів харчування, крім зазначених вище факторів, відбулося під впливом низки фракторів пропозиції, дія яких була потужнішою і тривалішою, ніж передбачалося. Зокрема, йдеться про високі врожаї: в Україні - зернових, овочів та окремих фруктів (зокрема, яблук), а в інших країнах - цитрусових [11, с. 36].

На фрормування споживчих цін у 2016 р. вплинули такі фрактори: скорочення пропозиції свинини та яловичини на внутрішньому ринку внаслідок зменшення обсягів вітчизняного виробництва та нарощування експорту; висока пропозиція обсягів постачання картоплі, овочів та плодів; поступове збільшення пропозиції на внутрішньому ринку зерна нового врожаю; відсутність на державному рівні адекватних компенсаторних заходів для нівелювання втрат внаслідок скасування адміністративного регулювання цін на соціально значущі продовольчі товари; незатребуваність передбачених українським законодавством цивілізованих механізмів регулювання ринків продовольчих ресурсів.

Принагідно зазначимо, що зростання цін на окремі продовольчі товари відбулося не у зв'язку з десріцитом продовольства, оскільки, згідно з балансовими розрахунками, Україна виробляє його достатньо для задоволення внутрішнього платоспроможного попиту і має потенціал до нарощування виробництва, а через падіння реальних доходів населення.

Розглянемо структуру сукупних витрат домогосподарств України із різними середньодушовими загальними доходами за 2016 рік (табл. 4).

Отже, аналіз даних щодо структури витрат домогосподарств України залежно від рівня доходів підтверджує, що зі зростанням середньодушових загальних доходів питома вага витрат домогосподарств як на продовольчі витрати, так і частка витрат на непродовольчі товари та послуги зменшується. Так, питома вага витрат домогосподарств на продовольчі товари у групі з найнижчими доходами у 1,13 раза перевищує аналогічний показник у групі домогосподарств $з$ найвищими доходами. 
Структура сукупних витрат домогосподарств України із різними середньодушовими загальними доходами в 2016 р. [12, с. 159].

\begin{tabular}{|c|c|c|c|c|}
\hline \multirow{2}{*}{$\begin{array}{c}\text { Середньодушові загальні } \\
\text { доходи на місяць, грн. }\end{array}$} & \multicolumn{4}{|c|}{ Частка сукупних витрат на одне домогосподарство, \% } \\
\hline & $\begin{array}{c}\text { продовольчі } \\
\text { товари } \\
\end{array}$ & $\begin{array}{c}\text { непродовольчі } \\
\text { товари та послуги }\end{array}$ & послуги & $\begin{array}{c}\text { неспоживчі сукупні } \\
\text { витрати } \\
\end{array}$ \\
\hline Усі домогосподарства & 52,7 & 25,5 & 15,0 & 6,8 \\
\hline До 480,0 & 57,6 & 27,4 & 14,4 & 0,6 \\
\hline $480,1-840,0$ & 66,4 & 21,5 & 10,6 & 1,5 \\
\hline $840,1-1200,0$ & 64,1 & 21,6 & 13,0 & 1,3 \\
\hline $1200,1-1560,0$ & 61,2 & 22,0 & 11,0 & 5,8 \\
\hline $1560,1-1920,0$ & 60,2 & 25,2 & 12,0 & 2,6 \\
\hline $1920,1-2280,0$ & 58,9 & 25,2 & 12,8 & 3,1 \\
\hline $2280,1-2640,0$ & 56,3 & 25,3 & 13,8 & 4,6 \\
\hline $2641,0-3000,0$ & 53,3 & 25,8 & 13,7 & 7,2 \\
\hline $3000,1-3360,0$ & 52,0 & 27,0 & 13,9 & 7,1 \\
\hline $3360,1-3720,0$ & 51,0 & 26,5 & 15,4 & 7,1 \\
\hline
\end{tabular}

Зміни в економіці України вплинули на витрати населення. Останніми роками зростають доходи населення, водночас витрати на харчування залишаються надзвичайно великими, що стримує розвиток інших витрат. Це призводить до зниження добробуту населення, впливає на неефективне формування і використання фінансових ресурсів.

Вагомий вплив на структуру споживання продуктів харчування чинять такі фактори, як соціально-демограсрічна структура домогосподарств, доходи та витрати населення, оскільки саме вони фрормують його купівельну спроможність. Співвідношення доходів, рівень і співвідношення цін (індекс споживчих цін на харчові продукти, показники роздрібного товарообороту, курс долара США до гривні) також справляють суттєвий вплив на рівень і структуру споживання продуктів харчування населенням України. Але на структуру споживання продуктів харчування чинять вплив й інші фрактори, серед яких присутні як такі, що склалися історично і мають стійкий характер (культура споживання і спосіб життя), так і такі, що з'явилися не так давно (психологічний вплив ЗМІ). Розглянемо класифікацію факторів впливу на структуру споживання продуктів харчування у (табл. 5).

Таким чином, зазначимо, що найбільший вплив на структуру споживання продуктів харчування населенням України чинять економічні фактори. Випередження темпів зростання сукупних витрат домогосподарств, рівень і співвідношення цін на продукти харчування та обов'язкові платежі примушують домогосподарства до економії i, як наслідок, покупки більш дешевих продуктів харчування. Зміни соціально-демограсрічних фракторів обмежують можливості отримання домогосподарством додаткових доходів родиною внаслідок необхідності утримання непрацездатних членів родини. Медико-біологічні фрактори вимагають збільшення витрат на корисні продукти харчування $з$ метою оздоровлення, оскільки у більшості домогосподарств спостерігаються негативні наслідки сучасної структури харчування, насамперед такі, як порушення 
Класифікація факторів, що впливають на структуру споживання продуктів харчування [13, с. 309].

\begin{tabular}{|c|c|}
\hline Група & Фактори \\
\hline Економічні & $\begin{array}{l}\text { Рівень сукупних доходів домогосподарств } \\
\text { Рівень сукупних витрат домогосподарств } \\
\text { Рівень і співвідношення цін на продукти харчування } \\
\text { Рівень витрат на обов'язкові платежі (комунальні послуги) }\end{array}$ \\
\hline Соціально-демографрічні & $\begin{array}{l}\text { Статево-віковий склад населення } \\
\text { Середній розмір домогосподарств } \\
\text { Кількість працюючих осіб у домогосподарстві }\end{array}$ \\
\hline Медично-біологічні & $\begin{array}{l}\text { Медико-біологічні норми споживання } \\
\text { Стан здоров'я населення }\end{array}$ \\
\hline Соціально-психологічні & $\begin{array}{l}\text { Культура споживання та спосіб життя населення } \\
\text { Особисті уподобання споживачів } \\
\text { Психологічний вплив ЗМІ (про здоровий спосіб життя) }\end{array}$ \\
\hline
\end{tabular}

харчового статусу. Соціально-демографрічні фактори теж обумовлюють певні особливості структури харчування: страви, притаманні українській нації, спосіб життя сучасної людини - "їжа нашвидкуруч" [13, с. 310].

Стан продовольчої безпеки України за більшістю показників задовольняє встановлені порогові значення та норми, однак його не можна характеризувати як стабільно позитивний. Вирішення проблем забезпечення продовольчої безпеки в Україні неможливе без фінансового регулювання цього процесу.

3 метою півищення фінансового забезпечення продовольчої безпеки варто вдосконалювати фінансову складову комплексного механізму продовольчої безпеки, яка має на меті забезпечення застосування економічних важелів і створення умов для залучення грошових ресурсів для функціонування системи забезпечення продовольчої безпеки шляхом формування системи багатоканального фінансування.

Особливу роль у забезпеченні продовольчої безпеки відіграють бюджетні важелі, які діють за двома напрямками: надання субсидій і дотацій сільськогосподарським виробникам та цільове бюджетне фінан- сування програм розвитку агропромислового комплексу. Найбільш поширеними за останні роки інструментами бюджетної політики щодо аграрного сектору економіки $€$ виробничі дотації у тваринництві та рослинництві, компенсація частини інвестицій на будівництво ферм і тепличних комплексів, закупівля обладнання для АПК на основі фрінансового лізингу, податкові пільги, мінімальні ціни, експортні та імпортні мита, регулювання цін на пальне та мінеральні добрива, фінансування соціальної інфрраструктури сільської місцевості $[14$, с. 47].

При цьому зауважимо, що ефективне аграрне виробництво $є$ основою забезпечення продовольчої безпеки держави, задоволення населення основними продуктами харчування в достатній кількості та різного асортименту. Проте проблеми розвитку аграрного сектору, актуальні тенденції цінової світової кон'юнктури на продовольчі ресурси, недостатня увага держави до проблем галузі створюють передумови для виникнення кризових явищ у забезпеченні населення продуктами харчування.

Один із головних підходів щодо управлінських структур державного рівня у сфері 
виробництва та перерозподілу продукції АПК (харчування) полягає в тому, щоб на оптимальному рівні здійснювати перерозподіл продукції АПК (харчування) всередині держави з метою забезпечення продовольчої безпеки регіонів, і лише після цього розглядати можливості їх експорту за межі України.

Висновки. На основі проведеного аналізу можемо зробити висновок, що вирішення проблем забезпечення продовольчої безпеки в Україні неможливе без фінансового регулювання цього процесу, адже усі проаналізовані індикатори залежать від фінансового становища виробника і кінцевого споживача продовольства.

Неможливо очікувати збільшення обсягів виробництва продукції без достатнього фінансового забезпечення сільськогосподарських виробників; з іншого боку - немає сенсу очікувати зростання рівня споживання продовольства за низького рівня купівельної спроможності населення.

Відтак, основними напрями удосконалення фрінансової системи з метою забезпечення продовольчої безпеки країни $є$ : доступність фінансово-кредитного забезпечення сільськогосподарських виробників; впровадження інновацій у сільськогосподарське виробництво; регулювання умов зовнішньої та внутрішньої торгівлі продовольством через систему тарифних і нетарифнних інструментів; системні заходи щодо зміцнення та подовження тривалості життя населення, збільшення рівня заробітної плати.

\section{Список використаних джерел}

1. Закон України "Про основи національної безпеки України" від 19.06.2003№ 964-IV (Редакція станом на 07.08.2015) [Електронний ресурс]. Режим доступу : zakon.rada.gov.ua/go/964-15

2. Державна цільова програма розвитку українського села на період до 2015 року [Електронний ресурс]. - Режим доступу : http://zakono. rada.gov.ua/laws/show/1158-2007-\%D0\%BF
3. Настич В.Г. Продовольча безпека як складова національної безпеки України / В.Г. Настич// Вісн. Бердянськ. у-ту менед. і бізнесу. 2013. - № 3 (23). - С. 43-48.

4. Саблук П.Т. Глобалізація іпродовольство/ П.Т. Саблук, О.Г. Білорус, В.І. Власов. - К. : ННЦ IAE, 2008. - $632 \mathrm{C}$.

5. Суперсон В.І. Системні підходи до вирішення проблем адміністративної рефоорми $у$ правовому полі України / В.І. Суперсон // Економіка. Фінанси. Право. - 2002. - № 6. - С. 7-14.

6. Статистичний щорічник Украйни за 2012 рік / за ред. О.Г. Осауленка ; відп. за вип. О.Е. Остапчук. - К. : ТОВ "Видав. "Інтерекспресдрук", 2013. - 551 c.

7. Статистичний щорічник України за 2015 рік / за ред. М.І. Жук; відп. за вил. О.А. Вишневська. - К. : Держаналітінфоорм, 2016. - 575 с.

8. Продовольча безпека в Україні у 2016 році. Оаляд основних індикаторів [Електронний ресурс] - Режим доcmyпy : http://edclub. com.ua/analityka/prodovolcha-bezpeka-v-ukrayiniu-2016-roci-oglyad-osnovnyh-indykatoriv

9. Статистичний збірник "Баланси та споживання основних продуктів харчування населенням України" / відп. за вип. О.М. Прокопенко / Державна служба статистики України, 2017. - 49 c.

10. Статистичний збірник "ндекси споживчих иін" / за ред. І.М. Жук ; відп. за вип. О.С. Балабуха / Державна служба статистики України, 2017 - $181 \mathrm{C.}$

11. Заячківська О.В. Аналіз наявного стану інфлячійних процесів у сучасній Украйні / О.В. Заячківська // Наук. вісн. Міжн. гуманітарного y-my. - 2017. - Вun. № 24-2. - С. 34-38.

12. Статистичний збірник "Витрати $i$ ресурси домогосподарств України у 2016 році (за даними вибіркового обстеження умов життя домогосподарств Украӥни)" / відп. за вип. I.I. Осипова. - 4. 1 / Державна служба статистики України, 2017. - 380 с.

13. Савченко Т.В. Фактори впливу на структуру споживання продуктів харчування 
населенням України / Т.В. Савченко // Економіка і суспільство. - 2016. - Вип. 5. - С. 304-310.

14. Карлова І.В. Фінансово-кредитні важелі забезпечення продовольчої безпеки України / I.В. Карпова // Молодий вчений. - 2016. - № 2 (29). - C. 45-48.

\section{References}

1. Zakon Ukrainy "Pro osnovy natsionalnoi bezpeky Ukrainy" vid 19.06.2003 № 964-IV [Law of Ukraine "On fundamentals of national security of Ukraine"] (2015, August, 07). Available at: http:// zakon.rada.gov.ua/go/964-15

2. Derzhavna tsilova prohrama rozvytku ukrainskoho sela na period do 2015 roku [State target program of Ukrainian village development till 2015]. Available at: http://zakono.rada.gov.ua/laws/ show $1158-2007-\% D 0 \% B F$

3. Nastych, V.H. (2013). Prodovolcha bezpeka yak skladova natsionalnoi bezpeky Ukrainy [Food safety as a component of Ukraine's national security]. Visnyk Berdianskoho universytetu menedzhmentuibiznesu-Bulletin of the Berdyansk university of management and business, 3 (23), 43-48 [in Ukrainian].

4. Sabluk, PT., Bilorus, O.H., Vlasov, VI. (2008). Hobalizatsiia i prodovolstvo [Globalization and provisions]. Kyiv: NNTs IAE [in Ukrainian].

5. Superson,VI. (2002). Systemni pidkhody do vyrishennia problem administratyvnoi reformy u pravovomu poli Ukrainy [Systemic approaches to solving administrative reform problems in the legal field of Ukraine]. Ekonomika. Finansy. Pravo Economy. Finances. Right, 6, 7-14 [in Ukrainian].

6. Osaulenko, O.H. (Ed.). (2013). Statystychnyi shchorichnyk Ukrainy za 2012 rik [Statistical yearbook of Ukraine for 2012]. Kyiv: TOV "Vydavnytstvo "Interekspresdruk" [in Ukrainian].

7. Zhuk, M.I. (Ed.). (2016). Statystychnyi shchorichnyk Ukrainy za 2015 rik [Statistical Yearbook of Ukraine for 2015]. Kyiv: Derzhanalitinform [in Ukrainian].

8. Prodovolcha bezpeka v Ukraini u 2016 rotsi. Ohliad osnovnykh indykatoriv [Food security in
Ukraine in 2016. Overview of the main indicators]. Available at: http://edclub.com.ua/analityka/ prodovolcha-bezpeka-v-ukrayini-u-2016-rocioglyad-osnovnyh-indykatoriv

9. Prokopenko, O.M. (2017). Statystychnyi zbirnyk "Balansy ta spozhyvannia osnovnykh produktiv kharchuvannia naselenniam Ukrainy" [Statistical compendium "Balances and consumption of basic foodstuffs by the population of Ukraine"]. Derzhavna sluzhba statystyky Ukrainy State statistics service of Ukraine [in Ukrainian].

10. Zhuk, I.M. (Ed.). (2017). Statystychnyi zbirnyk "Indeksy spozhyvchykh tsin" [Statistical compendium "Consumer price indices"]. Derzhavna sluzhba statystyky Ukrainy - State statistics service of Ukraine [in Ukrainian].

11. Zaiachkivska, O.V. (2017). Analiz naiavnoho stanu infliatsiinykh protsesiv u suchasnii Ukraini [Analysis of the current state of inflationary processes in modern Ukraine]. Naukovyi visnyk Mizhnarodnoho humanitarnoho universytetu Scientific bulletin of the international humanitarian university, 24-2, 34-38 [in Ukrainian].

12. Osypova, I.I. (2017). Statystychnyi zbirnyk "Vytraty i resursy domohospodarstv Ukrainy u 2016 rotsi (za danymy vybirkovoho obstezhennia umov zhyttia domohospodarstv Ukrainy)" [Statistical compendium "Costs and resources of households of Ukraine in 2016 (according to the sample survey of living conditions of households in Ukraine)"]. (Vol. 1). Derzhavna sluzhba statystyky Ukrayiny State statistics service of Ukraine [in Ukrainian].

13. Savchenko, T.V. (2016). Faktory vplyvu na strukturu spozhyvannia produktiv kharchuvannia naselenniam Ukrainy IFactors influencing the structure of food consumption by the population of Ukraine]. Ekonomika i suspilstvo - Economics and society, 5, 304-310 [in Ukrainian].

14. Karpova, I.V (2016). Finansovo-kredytni vazheli zabezpechennia prodovolchoi bezpeky Ukrainy [Financial lenders support for food safety of Ukraine]. Molodyi vchenyi - Young scientist, 2 (29), 45-48 [in Ukrainian].

Стаття надійшла до редакції 4.09.2017. 